\title{
Marine engine indicated power uncertainty determination
}

\begin{abstract}
A proposal of marine engine indicated power uncertainty evaluation method was presented. The uncertainties of the indicated power definitional formula components were evaluated. Methods of uncertainty estimation for measurement carried out in industrial conditions were proposed. A new component called a phase shift angle, in modified formula for the piston kinetic was introduced. The indicated power uncertainty was divided into two calculable parts called uncertainty category I and uncertainty category II. The results of the uncertainties determined for two marine engines: trunk piston and cross-head type were presented. The influence of the individual component of indicated power formula for the overall indicated power uncertainty value was shown.
\end{abstract}

Key words: marine diesel engine, indicated power, uncertainty

\section{Wyznaczanie niepewności mocy indykowanej silnika okrętowego}

\begin{abstract}
Zaprezentowano propozycję metody oceny niepewności mocy indykowanej silnika okrętowego. Określono niepewności składników definicyjnego równania mocy indykowanej. Przedstawiono metody szacowania niepewności dla pomiarów przeprowadzonych w warunkach przemysłowych. W zmodyfikowanym równaniu ruchu tłoka wprowadzono nowa wielkość fizyczna określona jako kąt przesunięcia fazowego. Zaproponowano także podziat niepewności mocy indykowanej na dwie obliczalne części, nazwane niepewnościa rodzaju I oraz niepewnościa rodzaju II. Przedstawiono wyniki niepewności wyznaczonych dla dwóch silników okrętowych: wodzikowego i bezwodzikowego. Zaprezentowano wpływ poszczególnych sktadników równania mocy indykowanej na wartość jej całkowitej niepewności.
\end{abstract}

Słowa kluczowe: silnik okrętowy, moc indykowana, niepewność

\section{Introduction}

In 1967 a comprehensive analysis of the internal combustion engine cycle work determination accuracy was carried out [1]. Since that time various papers aimed at the possibility of determining indicated work or power uncertainty reduction. Almost all of them point to the TDC positioning error on the indicator diagram as the main source of indicated power inaccuracy. Usually the indicated power error is taken as $3-10 \%$ of the measured indicated power value due to $1^{\circ} \mathrm{CA}$ error in TDC positioning [1, 6-9]. A methodology of indicated power uncertainty determination is not described clearly in the literature. However it might be useful in both laboratory and commercial indicator applications. Today available indicators do not even offer an approximate uncertainty evaluation.

The indicated power, like other physical or technical values, is determined with a specific uncertainty whose value should be attached to the measurement result. Knowledge of the uncertainty value as well as its main sources is crucial for the proper evaluation of the engine's indicator diagram. It can also be essential in more and more common systems of the engine tuning in a closed feed-back loop like the latest Wärtsilä Intelligent Combustion Control (ICC) system or MAN Auto Tuning applied in the ME C 9.2 series engines.

The main reason for lack of the indicated power uncertainty evaluation lies in the great dependency of the measured indicated power value on parameters independent from the instrument properties. Amongst others, the influence of the indicating channel on the recorded in-cylinder pressure value [8-10] and the piston TDC detection accuracy are the most significant. Because the TDC detection accuracy greatly

\section{Wprowadzenie}

W roku 1967 przeprowadzona została wyczerpująca analiza dokładności wyznaczania pracy obiegu silnika spalinowego [1]. Od tego czasu wielu badaczy zajmowało się możliwościami obniżenia niepewności wartości wyznaczonej pracy lub mocy indykowanej. W prawie wszystkich pracach związanych $\mathrm{z}$ tematem wskazuje się na problem dokładności odwzorowania położenia GMP tłoka na wykresie indykatorowym jako główne źródło niepewności mocy indykowanej. Zwykle podaje się, że błąd położenia GMP wynoszący $1^{\circ}$ obrotu wału korbowego (OWK) prowadzi do błędu w wyznaczonej wartości mocy indykowanej rzędu 3-10\% wartości zmierzonej [1, 6-9]. Pomimo że znajomość niepewności wyznaczonej mocy indykowanej byłaby cenna w zastosowaniach zarówno laboratoryjnych, jak i przemysłowych, jednak brak jest źródeł literaturowych opisujących ściśle metodykę jej wyznaczania. Dostępne obecnie komercyjne indykatory nie oferują nawet przybliżonego szacowania niepewności wykonanego nimi pomiaru.

Moc indykowana, podobnie jak inne wielkości fizyczne, jest wyznaczana z określoną niepewnością i wartość tej niepewności powinna być składową częścią uzyskanego wyniku pomiaru. Znajomość wartości niepewności jak również jej głównych źródeł jest podstawą prawidłowej oceny wykresu indykatorowego silnika. Może też mieć istotne znaczenie w coraz częściej spotykanych układach regulacji parametrów pracy silnika w pętli sprzężenia zwrotnego. Przykładami takich rozwiązań w silnikach okrętowych są konstrukcje firmy Wärtsilä: Intelligent Combustion Control (ICC) oraz firmy MAN: Auto Tuning System zastosowany w silnikach serii ME w wersji 9.2. 
depends on the sensor installation precision, its uncertainty can be estimated on the basis of measuring person's experience. Such procedure is justified in case of a limited amount of input data for uncertainty calculation [2]. The proposed method is meant to be applicable in a typical industrial digital indicator as an additional feature enabling the uncertainty estimation.

The entire process of the uncertainty determination should comply with the indicated power defining formula:

$$
P_{i}=\frac{L_{i}}{\tau_{c}}=\frac{L_{i} \cdot \omega}{2 n_{R} \pi}
$$

where: $\mathrm{P}_{\mathrm{i}}$ - indicated power [W], $\mathrm{L}_{\mathrm{i}}$ - indicated work [J], $\tau_{c}$ - engine cycle time $[\mathrm{s}], \omega-$ crankshaft's average angular speed $[\mathrm{rad} / \mathrm{s}], \mathrm{n}_{\mathrm{R}}$ - number of crankshaft revolutions per engine cycle.

For which the indicated work is calculated using the equation:

$$
\mathrm{L}_{\mathrm{i}}=\oint \mathrm{p} \cdot \mathrm{dV}=\mathrm{A} \oint \mathrm{p} \cdot \mathrm{dS}
$$

where: A - piston surface $\left[\mathrm{m}^{2}\right], \mathrm{p}$ - in-cylinder pressure $[\mathrm{Pa}], \mathrm{dS}$ - piston displacement $[\mathrm{m}], \mathrm{dV}$-cylinder change of volume $\left[\mathrm{m}^{3}\right]$.

The uncertainty of the indicated power can be considered as a result of the uncertainty of the indicated work developed during the engine cycle and uncertainty of crankshaft angular speed. While evaluation of the crankshaft angular speed uncertainty does not pose any difficulty, the indicated work uncertainty determination is much more complex. In order to simplify the task all components of the indicated power formula (1) can be divided into two groups:

1) with calculable uncertainty,

2) with estimable uncertainty.

The uncertainties of the first group can be objectively and quantitatively evaluated on the basis of the measurements carried out with the aid of the designated measuring instruments characterized by specific accuracy parameters. The uncertainties of the second group can be estimated solely on the basis of the measurer knowledge and experience. For the purpose of the uncertainty expression the symbols and the nomenclature complying with ISO standards were used [2].

\section{Uncertainty of engine geometry}

For the piston surface A calculation the nominal cylinder bore is usually taken. In practice even new cylinder diameter is seldom equal to the nominal. The real value of cylinder diameter is a function of a its working hours and engine's working conditions, mainly load, charging air humidity, quality of lubrication and fuel oil grade. If a valid cylinder diameter measurement protocol is available, an avarege value and a standard deviation can be easily calculated. Otherwise, the nominal diameter can be considered as the expected value and at the same time as the lower limit of the possible value range. The upper limit is equal to the maximum wear limit
Główną przyczyną trudności w określaniu niepewności mocy indykowanej jest silny wpływ parametrów pomiaru, niezależnych od właściwości przyrządu pomiarowego, na wartość zmierzonej mocy indykowanej. Spośród innych przyczyn wyróżnić należy przede wszystkim wpływ kanału indykatorowego na pomiar ciśnienia cylindrowego [8-10] oraz dokładność odwzorowania GMP tłoka. Ta dokladność odwzorowania zależy głównie od dokładności instalacji czujnika i jej niepewność może być oszacowana przede wszystkim na podstawie doświadczenia i subiektywnej oceny osoby wykonującej pomiar. Takie postępowanie jest uzasadnione przy ograniczonej liczbie danych do obliczenia niepewności [2]. Prezentowana metoda w założeniu powinna nadawać się do zastosowania w typowym przemysłowym indykatorze cyfrowym jako rozwinięcie jego funkcji o moduł umożliwiający oszacowanie niepewności.

Proces określania niepewności powinien być w całości zgodny $\mathrm{z}$ równaniem definicyjnym mocy indykowanej - wzór (1), gdzie: $\mathrm{P}_{\mathrm{i}}$ - moc indykowana [W], $\mathrm{L}_{\mathrm{i}}$ - praca indykowana $[\mathrm{J}], \tau_{\mathrm{c}}-$ czas trwania cyklu pracy silnika $[\mathrm{s}]$, $\omega$ - średnia prędkość kątowa wału korbowego [rad/s], $n_{R}$ - liczba obrotów wału korbowego w cyklu pracy silnika, w którym praca indykowana obliczana jest za pomocą równania (2), gdzie: A - powierzchnia denka tłoka $\left[\mathrm{m}^{2}\right], \mathrm{p}-$ ciśnienie wewnątrz cylindrowe $[\mathrm{Pa}], \mathrm{dS}$ - przemieszczenie tłoka $[\mathrm{m}], \mathrm{dV}$ - zmiana objętości komory spalania $\left[\mathrm{m}^{3}\right]$.

$\mathrm{Na}$ podstawie powyższych zależności niepewność mocy indykowanej może być rozpatrywana jako rezultat występowania niepewności wartości pracy indykowanej wytworzonej podczas cyklu pracy silnika oraz niepewności wartości prędkości kątowej wału korbowego. Podczas gdy określenie niepewności wartości prędkości kątowej wału nie przedstawia trudności, to określenie niepewność wartości pracy indykowanej jest znacznie bardziej złożone. Dla uproszczenia wszystkie składniki równania (1) można podzielić na dwie grupy:

1) wielkości z obliczalną niepewnością

2) wielkości z szacowalną niepewnością.

Niepewności wielkości z pierwszej grupy mogą być obiektywnie i ilościowo ocenione na podstawie pomiarów dokonanych przyrządami o określonej dokładności pomiaru. Niepewności wielkości z drugiej grupy mogą być jedynie oszacowane na podstawie doświadczenia i wiedzy osoby wykonującej pomiar. W niniejszej pracy na potrzeby wyrażania niepewności przyjęto oznaczenia i nazewnictwo zgodnie z zaleceniami ISO [2].

\section{Niepewność wielkości geometrycznych silnika}

Do obliczenia powierzchni denka tłoka A zazwyczaj przyjmuje się nominalną średnicę cylindra. W rzeczywistości średnica nawet nowej tulei cylindrowej rzadko jest równa średnicy nominalnej. Faktyczna wartość średnicy cylindra jest funkcją jej godzin pracy i warunków pracy silnika, w szczególności jego obciążenia, wilgotności powietrza doładowującego, jakości smarowania i rodzaju paliwa. Jeśli dostępny jest aktualny protokół pomiaru średnicy tulei, może on być z powodzeniem wykorzystany do określenia średniej wartości oraz odchylenia standardowego wartości średnicy. 
given by the engine maker. The width of this tolerance should be understood as a range comprising all possible cylinder diameters measured over its exploitation period. A uniform distribution model seems to be the most adequate for the standard uncertainty calculation:

$$
\mathrm{u}_{\mathrm{B}}\left(\mathrm{D}_{\mathrm{n}}\right)=\frac{\Delta \mathrm{D}_{\mathrm{n}}}{2 \sqrt{3}}
$$

where: $\mathrm{u}_{\mathrm{B}}\left(\mathrm{D}_{\mathrm{n}}\right)$ - cylinder liner's diameter standard uncertainty type $B[\mathrm{~m}], \Delta \mathrm{D}_{\mathrm{n}}$ - cylinder liner wear limit $[\mathrm{m}]$.

Therefore the piston surface standard uncertainty type B is found from equation:

$$
\mathrm{u}_{\mathrm{B}}(\mathrm{A})=\frac{\partial \mathrm{A}}{\partial \mathrm{D}_{\mathrm{n}}} \mathrm{u}_{\mathrm{B}}\left(\mathrm{D}_{\mathrm{n}}\right)=\frac{\pi \mathrm{D}_{\mathrm{n}}}{2} \mathrm{u}_{\mathrm{B}}\left(\mathrm{D}_{\mathrm{n}}\right)
$$

where: $u_{B}(A)$ - piston surface standard uncertainty type $B$ $\left[\mathrm{m}^{2}\right], \mathrm{D}_{\mathrm{n}}-$ cylinder liner nominal diameter $[\mathrm{m}]$.

The crank length can be easily derived from the engine manual. Much more problematic is the connecting rod length. It is usually not given in the manual and direct measurement has to be carried out. Then the connecting rod length measurement uncertainty has to be applied accordingly. The value of available measurement accuracy $\Delta \mathrm{l}$ carried out on board the vessel can be assumed as $1 \mathrm{~mm} / 1 \mathrm{~m}$ of the connecting rod length for trunk piston engines and for $2 \mathrm{~mm} / 1 \mathrm{~m}$ of the connecting rod length for crosshead engines.

Both, the crankshaft and the connecting rod are fit into sliding bearings at both ends. It is likely, that they do not operate exactly in their theoretical rotation axes. The rotation axis offset is limited by the value of the bearing clearance. Again the uniform distribution seems to be the most adequate for the uncertainty determination. The crank length uncertainty can be found from the formula:

$$
u_{B}(r)=\sqrt{\left(\frac{M_{c}}{2 \sqrt{3}}\right)^{2}+\left(\frac{C_{c}}{2 \sqrt{3}}\right)^{2}}
$$

where: $\mathrm{u}_{\mathrm{B}}(\mathrm{r})$ - crank length standard uncertainty type B $[\mathrm{m}], \mathrm{M}_{\mathrm{c}}-$ main bearing clearance $[\mathrm{m}], \mathrm{C}_{\mathrm{c}}-$ crank bearing clearance $[\mathrm{m}]$, and the connecting rod:

$$
\mathrm{u}_{\mathrm{B}}(\mathrm{l})=\sqrt{\left(\frac{\mathrm{C}_{\mathrm{c}}}{2 \sqrt{3}}\right)^{2}+\left(\frac{\mathrm{G}_{\mathrm{c}}}{2 \sqrt{3}}\right)^{2}+\left(\frac{\Delta \mathrm{l}}{\sqrt{3}}\right)^{2}}
$$

where: $\mathrm{u}_{\mathrm{B}}(\mathrm{l})$ - connecting rod length standard uncertainty type $\mathrm{B}[\mathrm{m}], \mathrm{G}_{\mathrm{c}}$ - gudgeon pin bearing clearance $[\mathrm{m}], \Delta \mathrm{l}-$ connecting rod length measurement accuracy [m]

\section{Uncertainty of pressure}

The problem of in-cylinder pressure measurement is a separate subject and it is well described in various publications $[1,8-10]$. Here the problem will be reduced to the measuring instrument accuracy only. However it should be
W przeciwnym razie jako wartość oczekiwana przyjmowana jest średnica nominalna. Stanowi ona zwykle dolną granicę przedziału, w którym mogą się znaleźć wszystkie możliwe średnice. Górną granicą jest średnica odpowiadająca maksymalnemu, dopuszczonemu przez producenta zużyciu tulei cylindrowej. Szerokość tak zdefiniowanego zakresu średnic powinna być rozumiana jako zakres obejmujący wszystkie średnice tulei, jakie mogą wystąpić podczas całego okresu eksploatacji tulei cylindrowej. Zastosowanie modelu rozkładu równomiernego wydaje się więc najbardziej uzasadnione do obliczenia niepewności standardowej średnicy cylindra - wzór (3), gdzie: $u_{B}\left(D_{n}\right)$ - niepewność standardowa typu B średnicy tulei cylindrowej $[\mathrm{m}], \Delta \mathrm{D}_{\mathrm{n}}$ - dopuszczalne zużycie tulei cylindrowej [m].

Konsekwentnie niepewność standardowa typu B powierzchni denka tłoka wyznaczana jest z zależności (4), gdzie: $\mathrm{u}_{\mathrm{B}}(\mathrm{A})$ - niepewność standardowa typu B powierzchni denka tłoka $\left[\mathrm{m}^{2}\right], \mathrm{D}_{\mathrm{n}}$ - nominalna średnica tulei cylindrowej $[\mathrm{m}]$.

Długość ramienia wykorbienia jest dostępna w dokumentacji silnika. Bardziej problematyczne jest określenie długości korbowodu. Zwykle nie jest ona podawana w dokumentacji silnika i przeważnie konieczne jest dokonanie jej bezpośredniego pomiaru. Wówczas należy również uwzględnić niepewność tego pomiaru. Osiągalną dokładność pomiaru długości korbowodu przeprowadzonego w warunkach eksploatacyjnych na statku można oszacować na $1 \mathrm{~mm} / 1 \mathrm{~m}$ długości korbowodu dla silników bezwodzikowych i na $2 \mathrm{~mm} / 1 \mathrm{~m}$ dla silników wodzikowych.

Zarówno wał korbowy, jak i korbowód osadzone są w łożyskach ślizgowych. Powoduje to, że elementy układu tłokowo-korbowego nie współpracują ze sobą dokładnie w swoich teoretycznych osiach obrotu. Występujące przesunięcie rzeczywistych osi obrotu elementów względem osi teoretycznej jest ograniczone wartością luzu łożyska ślizgowego. Ponownie model równomiernego rozkładu prawdopodobieństwa wydaje się najodpowiedniejszy w celu wyznaczenia niepewności. Niepewność długości ramienia korby może być zatem wyznaczona $\mathrm{z}$ równania (5), gdzie: $\mathrm{u}_{\mathrm{B}}(\mathrm{r})$ - niepewność standardowa typu $\mathrm{B}$ długości ramienia korby [m], M - luz łożyska głównego [m], C - luz łożyska korbowego [m], a niepewność długości korbowodu $z$ równania (6), gdzie: $u_{B}(1)-$ niepewność standardowa typu B długości korbowodu [m], $\mathrm{G}_{\mathrm{c}}$ - luz łożyska sworznia tłoka [m], $\Delta \mathrm{l}$ - dokładność pomiaru długości korbowodu [m]

\section{Niepewność pomiaru ciśnienia}

Problem pomiarów szybkozmiennych ciśnień wewnątrz cylindrowych stanowi samodzielne zagadnienie i jest on szczegółowo opisany w wielu publikacjach [1, 8-10]. W niniejszej pracy będzie on ograniczony wyłącznie do zagadnienia określenia dokładności przyrządu pomiarowego. Jednakże trzeba podkreślić, że na dokładność pomiaru ciśnienia wewnątrz cylindra wpływa znaczna liczba czynników, a najważniejsze $\mathrm{z}$ nich to: miejsce zainstalowania czujnika ciśnienia, zjawisko rezonansu słupa gazu w kanale indykatorowym, jakość układu do pomiaru ciśnień oraz wpływ gwałtownych zmian temperatury i stan samego kanału indykatorowego [3]. 
noted that there are many factors, such as sensor position, pressure resonance in gas passage, quality of the pressure signal measuring system, the state of the indication channel [3] and temperature impact, which greatly influence the measurement accuracy.

In case of indicators used in the marine industry, the pressure sensor's linearity is usually within $1 \%$ of full scale range (FSO). Typical acquisition system is generally characterized by a much lower uncertainty then the sensor therefore it can be neglected. The standard uncertainty type B of a single pressure sample can be found with formula:

$$
\mathrm{u}_{\mathrm{B}}\left(\mathrm{p}_{\mathrm{z}}\right)=\frac{\mathrm{R} \cdot \Delta \mathrm{p}}{100 \% \sqrt{3}}
$$

where: $u_{B}\left(p_{z}\right)$ - measured pressure sample standard uncertainty type $\mathrm{B}[\mathrm{Pa}], \mathrm{R}$ - sensor's measuring range $[\mathrm{Pa}], \Delta \mathrm{p}$ - pressure sensor's linearity error [\%].

In order to determine the indicated power, the pressure measurement has to be integrated with respect to the piston displacement dS (equation (2)). The trapezoidal integration method is usually applied. So as to determine the surface of an elementary trapezoid the average pressure value pav of two consecutive pressure samples $\mathrm{p}_{\mathrm{z}}$ and $\mathrm{p}_{\mathrm{z}+1}$ has to be calculated. The consecutive pressure samples are correlated with a correlation coefficient $r\left(p_{1+z-1}, p_{2+z}\right)$ close to unity. Therefore a formula for correlated input data might be used [2]:

$$
u_{B}\left(p_{a v}\right)=\sqrt{\begin{array}{l}
u_{B}^{2}\left(p_{z}\right)+u_{B}^{2}\left(p_{z+1}\right)+ \\
+2 u_{B}\left(p_{z}\right) \cdot u_{B}\left(p_{z+1}\right) \cdot r\left(p_{1+z-1}, p_{2+z}\right)
\end{array}}
$$

where: $u_{B}\left(p_{a v}\right)$ - the average of two consecutive pressure samples standard uncertainty type $\mathrm{B}[\mathrm{Pa}]$.

The uncertainty $\mathrm{u}_{\mathrm{B}}\left(\mathrm{p}_{\mathrm{av}}\right)$ of the average pressure is constant and depends solely on the measuring instrument parameters not on the measured pressure value. The correlation coefficient $\mathrm{r}$ can be easily calculated from the pressure values measured over engine cycle.

\section{Uncertainty of speed and time measurement}

The crankshaft angular speed measurement uncertainty is related to the measurement method and the measured propulsion unit properties. The common method is based on a singular pick-up sensor generating one or more pulses per revolution. It is assumed that the angular speed between pulses is uniform. That is a simplification as exact measurements shows that the periodical accelerations and decelerations over one crankshaft revolution can be observed [5]. Those speed fluctuations are known as the speed nonuniformity.

Direct measurements on boards seafaring vessels revealed, that in case of the marine slow speed engine, directly driving the ship's propeller, the nonuniformity can exceed $15 \%$ in the proximity of the barred speed range. As a consequence the relative uncertainty type A of the angular speed measurement varies from $6 \%$ for the engine operating close to barred speed range to $1 \%$ (Fig. 1). As long as the engine indication is carried out far outside the resonant speed range
Do budowy indykatorów przeznaczonych do zastosowania w przemyśle okrętowym najczęściej stosuje się piezoelektryczne czujniki ciśnienia, których nieliniowość nie przekracza zwykle 1\% zakresu pomiarowego. Układy wzmacniające i kondycjonujące sygnał pomiarowy przeważnie charakteryzują się znacznie lepszymi parametrami, więc ich wpływ na niepewność pomiaru może być pominięty. Wówczas niepewność standardowa typu B pojedynczej próbki ciśnienia obliczana jest z zależności (7), gdzie: $u_{B}\left(p_{z}\right)$ - niepewność standardowa typu B pomiaru pojedynczej próbki ciśnienia $[\mathrm{Pa}], \mathrm{R}$ - zakres pomiarowy czujnika [Pa], $\Delta \mathrm{p}$ - błąd liniowości czujnika ciśnienia [\%].

Aby wyznaczyć moc indykowaną, zmierzony przebieg ciśnienia jest całkowany względem przemieszczenia tłoka dS (równanie (2)). Zwykle całkowanie odbywa się numeryczną metodą trapezów, dlatego aby określić powierzchnię elementarnego trapezu, konieczne jest obliczenie wartości średniej $\mathrm{p}_{\mathrm{av}} \mathrm{z}$ dwóch sąsiadujących zmierzonych próbek ciśnienia $\mathrm{p}_{\mathrm{z}}$ oraz $\mathrm{p}_{\mathrm{z}+1}$. Zbiory liczb obejmujące $\mathrm{z}$ kolejnych próbek ciśnienia są ze sobą skorelowane, przy czym współczynnik korelacji $\mathrm{r}\left(\mathrm{p}_{1+\mathrm{z}-1}, \mathrm{p}_{2+\mathrm{z}}\right)$ przyjmuje wartości bliskie jedności. Zatem do wyznaczenia niepewności wartości średniej $\mathrm{p}_{\mathrm{av}}$ stosuje równanie dla danych skorelowanych [2] (8), gdzie: $\mathrm{u}_{\mathrm{B}}\left(\mathrm{p}_{\mathrm{av}}\right)$ - niepewność standardowa typu B średniej z kolejnych par próbek ciśnienia $[\mathrm{Pa}]$.

Niepewność $\mathrm{u}_{\mathrm{B}}\left(\mathrm{p}_{\mathrm{av}}\right)$ średniej kolejnych par próbek ciśnienia jest stała i zależy wyłącznie od właściwości układu pomiarowego, nie zaś od samej wartości zmierzonego ciśnienia. Wartość współczynnika korelacji r może być łatwo określona na podstawie zbioru próbek ciśnienia zarejestrowanych w cyklu pracy silnika.

\section{Niepewność pomiaru czasu i prędkości}

Wartość niepewności pomiaru prędkości kątowej wału korbowego jest ściśle powiązana z metodą pomiaru oraz właściwościami układu napędowego. Powszechnie stosowaną metodą wyznaczania prędkości jest pomiar częstotliwości impulsów z czujnika generującego sygnał raz na obrót wału. Zakłada się przy tym, że prędkość kątowa w czasie pomiędzy kolejnymi zarejestrowanym impulsami jest stała. Założenie takie jest dużym uproszczeniem, ponieważ dokładniejsze pomiary pokazują występowanie okresowych przyspieszeń i opóźnień prędkości kątowej wału korbowego podczas pojedynczego obrotu [5]. Takie fluktuacje prędkości określane są mianem niejednostajności biegu (lub nierównomierności prędkości obrotowej) silnika.

Pomiary przeprowadzone przez autora tej publikacji na pokładzie statku morskiego wskazują, że w odniesieniu do silnika wolnoobrotowego bezpośrednio napędzającego śrubę okrętową, niejednostajność biegu jest zmienna i może przekraczać $15 \%$ w pobliżu zakresu prędkości krytycznych. W konsekwencji względna niepewność typu A prędkości kątowej wału jest również zmienna i może osiągać wartości od $1 \%$ do $6 \% \mathrm{w}$ pobliżu zakresu prędkości krytycznych (rys. 1). Jeżeli prędkość badanego silnika jest wystarczająco różna od prędkości krytycznych, do obliczeń można przyjąć wartość względnej niepewności prędkości kątowej typu A, wynoszącą 1\% prędkości zmierzonej. 


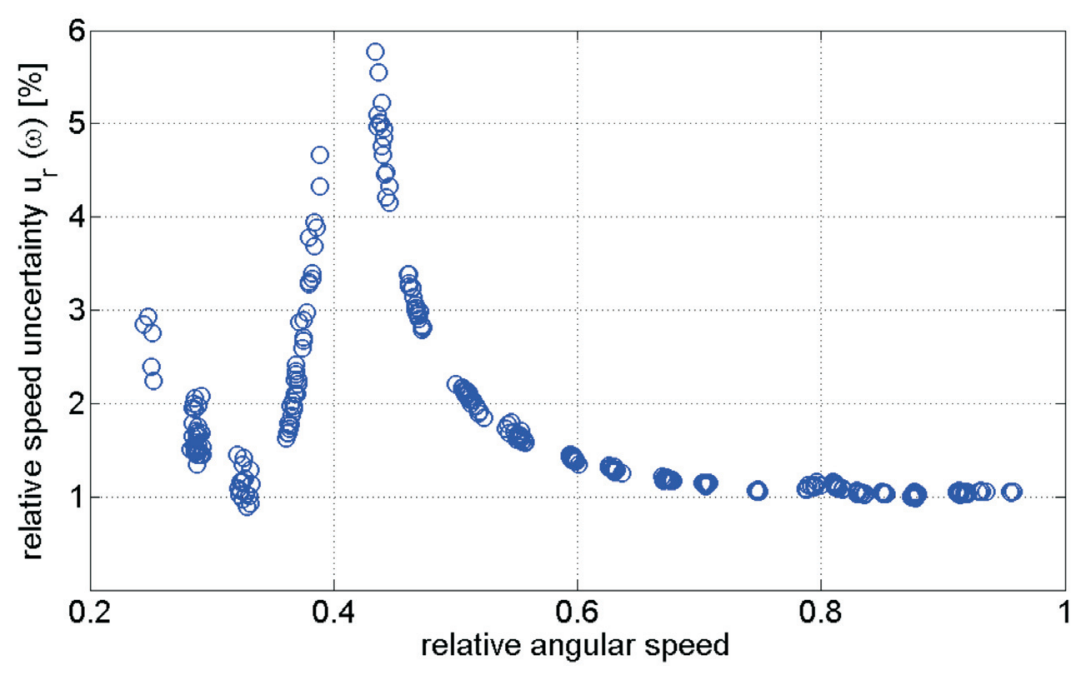

Fig. 1. MAN 6L70 ME-C engine angular speed measurement relative uncertainty Rys. 1. Względna niepewność pomiaru prędkości kątowej silnika MAN 6 L70 ME-C
Dla bezwodzikowych silników średnioobrotowych niejednostajność biegu może znacznie się różnić od wartości charakteryzujących silniki wolnoobrotowe. Większość silników średnioobrotowych przystosowana jest do napędu prądnic synchronicznych ze stałą prędkością obrotową, co skutkuje wyższymi wymaganiami stawianymi w odniesieniu do ich prędkości w porównaniu do silników wolnoobrotowych. Pomiary przeprowadzone na silniku firmy Sulzer typu 6Al 20/24 wskazują, że względne odchylenie standardowe prędkości kątowej wału korbowego, czyli względna niepewność typu A tej prędkości kątowej, nie przekraczają wartości $0,4 \%$.

Właściwości układu pomiarowego powinny być również uwzględnione. Jeżeli nie podano niepewności właściwej dla zastosowanego układu pomiarowego, może ona być określona w sposób

the angular speed measurement relative uncertainty type A is close to $1 \%$ of the measured value.

In case of trunk piston engine the speed nonuniformity may be much different. Most of them are prepared for driving synchronous generators with constant speed, which implicates much stricter demands regarding the engine speed compared to slow speed engines. The measurements carried out by the author on Sulzer 6Al 20/24 engine revealed that the relative standard deviation of the crankshaft angular speed and consequently speed relative uncertainty type A was not exceeding the value of $0.4 \%$.

The measuring equipment properties should be considered as well. If there is no specific uncertainty given, the speed measurement uncertainty can be determined in a simplified way. Most of the commercial marine indicators are able to scan engines with a maximum speed of 1500 rpm. In order to get at least 360 samples per revolution a minimum sampling rate of $9 \mathrm{kHz}$ is required. Therefore the angular speed measurement is usually performed at sampling rate of $10-25 \mathrm{kHz}$. Assuming the worst case for the lower sampling rate of $10 \mathrm{kHz}$ and the highest engine speed of $1500 \mathrm{rpm}$ the speed measurement maximum error due to digitalization process is not exceeding $0.3 \%$. However the operating speed of most of main propulsion engines is below $500 \mathrm{rpm}$ and the error can be assumed as $0.1 \%$ or even less. If a uniform distribution model is applied again, the relative standard uncertainty of the speed measurement is in the range $u_{\mathrm{rA}}(\omega)=0.06-0.17 \%$.

The combined speed measurement relative uncertainty can be found as a geometrical sum of two components:

$$
u_{\mathrm{rC}}(\omega)=\sqrt{\mathrm{u}_{\mathrm{rA}}^{2}(\omega)+\mathrm{u}_{\mathrm{rB}}^{2}(\omega)}
$$

where: $u_{r C}(\omega)$ - the combined relative uncertainty of the speed measurement $[\%], \mathrm{u}_{\mathrm{rA}}(\omega)$ - the speed measurement relative uncertainty (type A) due to the speed nonuniformity [\%], uproszczony. Większość indykatorów stosowanych w żegludze umożliwia dokonywanie pomiarów na silnikach, których prędkość obrotowa nie przekracza 1500 obr/min. Aby możliwe było uzyskanie przynajmniej 360 próbek pomiarowych na jeden obrót wału korbowego, najmniejsza wymagana częstotliwość próbkowania sygnałów musi wynosić $9 \mathrm{kHz}$. Z tego względu w praktyce stosowane są zwykle częstości próbkowania wynoszące 10 do 25 kHz. Przy założeniu skrajnie niekorzystnego przypadku, kiedy częstotliwość próbkowania wynosi $10 \mathrm{kHz}$, a prędkość obrotowa silnika wynosi 1500 obr/min, względny błąd pomiaru prędkości kątowej ze względu na częstość próbkowania nie przekracza $0,3 \%$. W większości jednak silniki napędu głównego statków pracują z prędkościami nieprzekraczającymi $500 \mathrm{obr} / \mathrm{min}$ i błąd ten wynosi wówczas zaledwie $0,1 \%$ lub mniej. Przy zastosowaniu ponownie modelu rozkładu równomiernego względna niepewność zmierzonej $\mathrm{w}$ ten sposób prędkości kątowej mieści się w zakresie $u_{\mathrm{rA}}(\omega)=0,06-0,17 \%$.

Złożona względna niepewność może być obliczona jako suma geometryczna dwóch składników - wzór (9), gdzie: $\mathrm{u}_{\mathrm{rC}}(\omega)$ - złożona względna niepewność pomiaru prędkości kątowej [\%], $\mathrm{u}_{\mathrm{rA}}(\omega)$ - względna niepewność pomiaru (typu A) prędkości kątowej ze względu na niejednostajność biegu silnika [\%], $\mathrm{u}_{\mathrm{rB}}(\omega)$ - względna niepewność pomiaru prędkości kątowej ze względu na cyfrową metodę pomiaru [\%].

$\mathrm{W}$ odniesieniu do wolnoobrotowych silników wodzikowych pracujących z prędkościami obrotowymi nieprzekraczającymi $150 \mathrm{obr} / \mathrm{min}$, niepewność pomiaru ze względu na częstość próbkowania nie przekracza wartości 5\% niepewności spowodowanej zjawiskiem nierównomierności biegu silnika. $\mathrm{Z}$ tego względu uzasadnione jest uproszczenie (10).

Jak wspomniano, minimalna wymagana częstość próbkowania sygnałów wynosi $10 \mathrm{kHz}$. Oznacza to, 
$\mathrm{u}_{\mathrm{rB}}(\omega)$ - the relative uncertainty of the speed measurement due to digitalization process [\%].

In case of low speed, cross-head engines, operating at speed less than $150 \mathrm{rpm}$, the uncertainty due to digitalization process is less than $5 \%$ of the uncertainty due to nonuniformity, therefore the following simplification is reasonable:

$$
\mathrm{u}_{\mathrm{rC}}(\omega)=\mathrm{u}_{\mathrm{rA}}(\omega)
$$

As it was mentioned above, the minimum required sampling frequency is $10 \mathrm{kHz}$. That means there is a uniform probability that the measured signal is sampled inside the time span of $\Delta t=100 \mu \mathrm{s}$. Therefore the standard uncertainty of time measurement can be found with aid of uniform distribution:

$$
\mathrm{u}_{\mathrm{B}}(\mathrm{t})=\frac{\Delta \mathrm{t}}{2 \sqrt{3}}=\frac{100 \mu \mathrm{s}}{2 \sqrt{3}} \cong 30 \mu \mathrm{s}
$$

where: $\mathrm{u}_{\mathrm{B}}(\mathrm{t})$ - time measurement standard uncertainty type $\mathrm{B}[\mathrm{s}], \Delta \mathrm{t}-$ the inverse of the sampling frequency of the analog signals $[\mathrm{s}]$.

\section{Uncertainty of piston position}

The piston position uncertainty can be estimated on the basis of the modified well known formula:

$$
\begin{aligned}
S(t) & =r\left(1-\cos \left(\omega t+\varphi_{s}\right)\right)+ \\
& +1 \cdot\left(1-\sqrt{1-\left(\frac{r}{1}\right)^{2} \sin ^{2}\left(\omega t+\varphi_{s}\right)}\right)
\end{aligned}
$$

where: $\mathrm{S}(\mathrm{t})$ - piston displacement as a time function [m], $\varphi_{\mathrm{s}}$ - phase shift angle [rad].

A new parameter - phase shift angle $\varphi_{\mathrm{s}}$ was introduced in that formula (this term was used in a similar meaning in [1]). It should be understood as a superposition of shaft lines manufacturing and assembling tolerances, the TDC pick-up installation precision, the dynamic errors from the torsional vibrations and the crankshaft under-load twisting. In case of a propulsion system of specific construction additional components may be added too. The phase shift angle is a result of the following equation:

$$
\varphi_{\mathrm{s}}=\varphi_{\mathrm{c}}+\varphi_{\mathrm{F}}+\varphi_{\mathrm{p}}+\varphi_{\mathrm{T}}+\varphi_{\mathrm{V}}
$$

where: $\varphi_{\mathrm{c}}-$ crank throw manufacturing and assembling tolerance [rad], $\varphi_{\mathrm{F}}-$ flying wheel marking and assembling tolerance [rad], $\varphi_{\mathrm{p}}-$ TDC pick-up installation accuracy [rad], $\varphi_{\mathrm{T}}$ - shaft under load twisting influence [rad], $\varphi_{\mathrm{V}}-$ torsional vibration influence [rad].

The expected value of every above mentioned angle components is zero. However every one of them is characterized by its own uncertainty (Tab. 1). Those uncertainties all together may have a significant impact on the final piston position uncertainty. In case of manufacturing tolerances a uniform distribution model of a measurand inside the tolerance range was applied for the standard uncertainty determination. Due to the fact, that there is little information about the distribution model of the shaft dynamic geometric że próbka mierzonego sygnału może z równym prawdopodobieństwem być zarejestrowana w przedziale czasowym wynoszącym $\Delta \mathrm{t}=100 \mu \mathrm{s}$ i dlatego niepewność standardową pomiaru czasu można wyznaczyć, korzystając z modelu rozkładu równomiernego (11), gdzie: $\mathrm{u}_{\mathrm{B}}(\mathrm{t})$ - niepewność standardowa typu B pomiaru czasu [s], $\Delta \mathrm{t}$ - odwrotność częstotliwości próbkowania sygnałów analogowych $[\mathrm{s}]$.

\section{Niepewność określenia położenia tloka}

Niepewność związana z określeniem położenia tłoka silnika może być wyznaczona na podstawie zmodyfikowanego równania kinematyki tłoka (12), gdzie: $\mathrm{S}(\mathrm{t})$ - przemieszczenie tłoka w funkcji czasu [m], $\varphi_{\mathrm{s}}-$ kąt przesunięcia fazowego [rad].

W równaniu (12) wprowadzono nowy parametr, nazwany kątem przesunięcia fazowego $\varphi_{\mathrm{s}}$ (takie określenie, $\mathrm{w}$ zbliżonym znaczeniu, użyte już było w publikacji [1]). Parametr ten powinien być rozumiany jako złożenie wpływu dokładności wykonania i montażu linii wałów, dokładności montażu znacznika położenia GMP tłoka, wpływu drgań skrętnych wału korbowego oraz jego skręcenia wskutek obciążającego momentu obrotowego. W szczególnych przypadkach możliwe jest wprowadzanie dodatkowych składników kąta $\varphi_{s}$. Zatem kąt przesunięcia fazowego można zdefiniować jako sumę wymienionych wcześniej składników - wzór (13), gdzie: $\varphi_{\mathrm{c}}$ - tolerancja wykonania i montażu ramion korby wału [rad], $\varphi_{\mathrm{F}}-$ tolerancja montaży i oznakowania koła zamachowego [rad], $\varphi_{\mathrm{P}}-$ dokładność mocowania czujnika położenia GMP [rad], $\varphi_{\mathrm{T}}$ - wpływ skręcenia wału obciążonego momentem obrotowym [rad], $\varphi_{\mathrm{V}}$ - wpływ drgań skrętnych wału [rad].

Wartość oczekiwana każdego z wyżej wymienionych składników wynosi zero, ale każdy z nich charakteryzuje się pewną, właściwą sobie, niepewnością (tab. 1). To wypadkowa tych niepewności może mieć znaczący wpływ na ostateczną niepewność położenia tłoka silnika. W przypadku tolerancji wykonania i montażu elementów konstrukcyjnych silnika do wyznaczenia niepewności standardowej zastosowano model rozkładu równomiernego wielkości mierzonej mieszczącej się $\mathrm{w}$ dopuszczalnym przedziale pola tolerancji. Ze względu na znikomą ilość informacji na temat możliwego do zastosowania modelu rozkładu zmian geometrii wału korbowego wskutek drgań skrętnych i obciążenia momentem obrotowym, również zastosowano model rozkładu równomiernego. Ostatecznie niepewność standardowa kąta przesunięcia fazowego obliczana jest z zależności (14).

Przy zastosowaniu przedstawionych założeń wartość kąta przesunięcia fazowego i jego niepewności dla silników wodzikowych wynosi:

$$
\varphi_{\mathrm{s}}=(0.000 \pm 0.010) \mathrm{rad}
$$

zaś dla silników bezwodzikowych:

$$
\varphi_{\mathrm{s}}=(0.000 \pm 0.011) \mathrm{rad}
$$

Przedstawione wartości niepewności mogą znacząco różnić się w indywidualnych przypadkach, wskazane jest więc przeprowadzenie szczegółowej analizy dla każdego przypadku układu napędowego. 
deformations the uniform distribution model was applied too. The final standard uncertainty of the phase shift angle can be calculated from formula:

$$
u_{B}\left(\varphi_{\mathrm{s}}\right)=\sqrt{\begin{array}{l}
u_{\mathrm{B}}^{2}\left(\varphi_{\mathrm{s}}\right)+\mathrm{u}_{\mathrm{B}}^{2}\left(\varphi_{\mathrm{F}}\right)+\mathrm{u}_{\mathrm{B}}^{2}\left(\varphi_{\mathrm{p}}\right)+ \\
+\mathrm{u}_{\mathrm{B}}^{2}\left(\varphi_{\mathrm{T}}\right)+\mathrm{u}_{\mathrm{B}}^{2}\left(\varphi_{\mathrm{V}}\right)
\end{array}}
$$

and a result for cross-head engines is:

$$
\varphi_{\mathrm{s}}=(0.000 \pm 0.010) \mathrm{rad}
$$

whilst for trunk piston engines:

$$
\varphi_{\mathrm{s}}=(0.000 \pm 0.011) \mathrm{rad}
$$

The values of both uncertainties may vary greatly from engine to engine and for every case an individual thorough analysis should be carried out.

\section{Overall indicated power uncertainty determination}

As an example for calculations, two engines of different construction were chosen:

- trunk piston engine Hyundai Himsen H25/33,

- cross-head engine MAN K90 MC-C.

The measurement of a single cylinder indicated power, carried out by means of a commercially available digital indicator, was analyzed. The total indicated power uncertainty type B can be considered as a combined uncertainty of two sources. The first is a combined uncertainty with respect to every single variable included in equations (1), (2) and (12). This part of the indicated power uncertainty can be named the uncertainty of category I. The second one is a direct result of the non-zero value of the phase shift angle uncertainty $\mathrm{u}_{\mathrm{B}}\left(\varphi_{\mathrm{s}}\right)$. This part of the indicated power uncertainty can be named the uncertainty of category II.

In order to determine the category I uncertainty the piston position measurement uncertainty $\mathrm{u}_{\mathrm{B}}(\mathrm{S})$ was calculated initially:

$$
\mathrm{u}_{\mathrm{B}}(\mathrm{S})=\sqrt{\begin{array}{l}
\left(\frac{\partial \mathrm{S}(\mathrm{t})}{\partial \mathrm{t}} \mathrm{u}_{\mathrm{B}}(\mathrm{t})\right)^{2}+\left(\frac{\partial \mathrm{S}(\mathrm{t})}{\partial \omega} \mathrm{u}_{\mathrm{c}}(\omega)\right)^{2}+ \\
+\left(\frac{\partial \mathrm{S}(\mathrm{t})}{\partial \varphi_{\mathrm{s}}} \mathrm{u}_{\mathrm{B}}\left(\varphi_{\mathrm{s}}\right)\right)^{2}+\left(\frac{\partial \mathrm{S}(\mathrm{t})}{\partial \mathrm{r}} \mathrm{u}_{\mathrm{B}}(\mathrm{r})\right)^{2}+ \\
\left(\frac{\partial \mathrm{S}(\mathrm{t})}{\partial \mathrm{l}} \mathrm{u}_{\mathrm{B}}(\mathrm{l})\right)^{2}
\end{array}}
$$

where: $u_{B}(S)$ - piston position determination standard uncertainty type $\mathrm{B}[\mathrm{m}], \mathrm{S}(\mathrm{t})$ - piston displacement as a function of time $[\mathrm{m}]$,

The value of $u_{B}(S)$ is independent from the instant piston position providing the crankshaft angular speed is assumed constant, therefore uncertainties of the consecutive piston positions $\mathrm{S}_{\mathrm{i}}$ are equal:

$$
\mathrm{u}_{\mathrm{B}}\left(\mathrm{S}_{\mathrm{i}}\right)=\mathrm{u}_{\mathrm{B}}\left(\mathrm{S}_{\mathrm{i}+1}\right)=\mathrm{u}_{\mathrm{B}}(\mathrm{S})
$$

The elementary piston displacement dSi between the consecutive samples can be found as a difference:

\begin{tabular}{|c|c|c|c|}
\hline $\begin{array}{c}\text { Angle } \\
\text { name/ } \\
\text { kat }\end{array}$ & $\begin{array}{c}\text { Tolerance } \\
\text { or maximal } \\
\text { error/toler- } \\
\text { ancje lub } \\
\text { btad } \Delta \varphi\end{array}$ & $\begin{array}{c}\text { Standard } \\
\text { uncertainty/ } \\
\text { niepewność } \\
\text { standar- } \\
\text { dowa } \mathrm{u}_{\mathrm{B}}(\varphi)\end{array}$ & Characteristic/charakterystyka \\
\hline$\varphi_{\mathrm{C}}$ & $\pm 0.5^{\circ}$ & $\pm 0.29^{\circ}$ & $\begin{array}{l}\text { Crank throw manufacturing and as- } \\
\text { sembling tolerance. The manufactur- } \\
\text { ing tolerance varies from } \pm 0.1^{\circ} \text { to } \\
\pm 0.5^{\circ} \text { independently from the type, size, } \\
\text { power, or manufacturer of the engine. } \\
\text { Tolerancja wykonania i montażu ramion } \\
\text { wykorbien watu korbowego; zwykle } \\
\text { mieści się w przedziale } \pm 0,1^{\circ} \text { do } \pm 0,5^{\circ} \text {, } \\
\text { jest niezależna od producenta, typu czy } \\
\text { wielkości silnika. }\end{array}$ \\
\hline$\varphi_{\mathrm{F}}$ & $\pm 0.5^{\circ}$ & $\pm 0.29^{\circ}$ & $\begin{array}{l}\text { Flying wheel marking and assembling } \\
\text { tolerance. It was assumed that the mark- } \\
\text { ing and assembling of flying wheel should } \\
\text { not exceed the tolerance of the crankshaft } \\
\text { manufacturing. /Tolerancja osadzenia na } \\
\text { wale i znakowania kota zamachowego. } \\
\text { Przyjeto, ze nie powinna ona przekraczac } \\
\text { wartości odchytek dla wykonania } \\
\text { i montazu watu korbowego. }\end{array}$ \\
\hline$\varphi_{\mathrm{p}}$ & $\begin{array}{c} \pm 0.2^{\circ} \text { to } \pm \\
0.5^{\circ}\end{array}$ & $\begin{array}{c} \pm 0.12^{\circ} \text { to } \pm \\
0.29^{\circ}\end{array}$ & 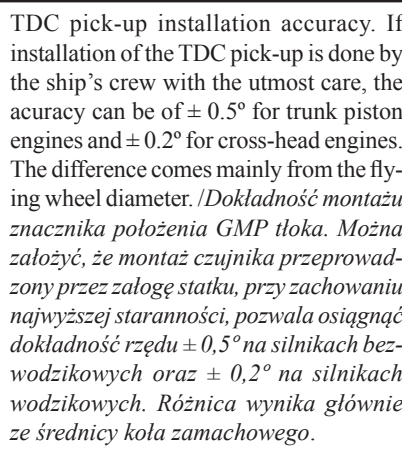 \\
\hline$\overline{\varphi_{\mathrm{T}}}$ & $0^{\circ}$ to $0.5^{\circ}$ & $0.14^{\circ}$ & 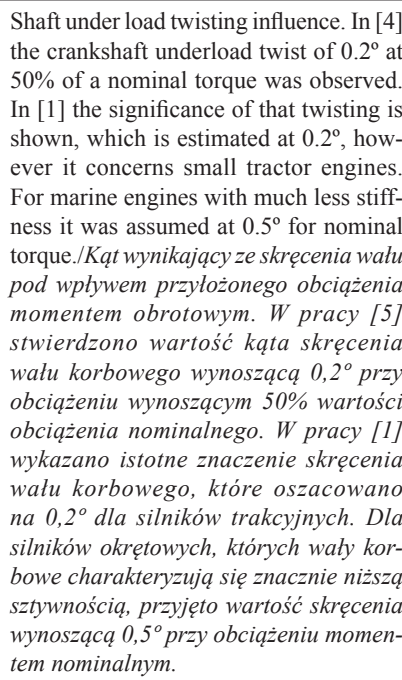 \\
\hline$\varphi_{\mathrm{v}}$ & $\pm 0.57^{\circ}$ & $\pm 0.33^{\circ}$ & $\begin{array}{l}\text { Torsional vibration influence. It was as- } \\
\text { sumed on the basis of Geislinger torsional } \\
\text { wibration monitoring system where the } \\
\text { alarm setpoint value is preset usually } \\
\text { at } \pm 10 \text { mrad }\left( \pm 0.57^{\circ}\right) \text {./Kat wynikajacy } \\
\text { z wplywu zjawiska drgań skretnych watu } \\
\text { korbowego. Przyjęto wartość progu } \\
\text { alarmowego uktadu do monitorowania } \\
\text { drgań skretnych firmy Geislinger, który } \\
\text { zwykle ustawiany jest na wartość } \pm 10 \\
\text { mrad }\left( \pm 0,57^{\circ} \text {. }\right.\end{array}$ \\
\hline
\end{tabular}

Table 1. The tolerances and standard uncertainties of the phase shift angle components with description

Tabela 1. Tolerancje i niepewności standardowe składników kąta przesunięcia fazowego wraz z opisem 


$$
\mathrm{dS}_{\mathrm{i}}=\mathrm{S}_{\mathrm{i}+1}-\mathrm{S}_{\mathrm{i}}
$$

Due to the fact that the consecutive piston positions are strongly correlated, with a correlation coefficient $r\left(\mathrm{~S}_{1+i-1}, \mathrm{~S}_{2+1}\right)$ approaching to unity, the elementary piston displacement uncertainty $\mathrm{u}_{\mathrm{B}}(\mathrm{dS})$ can be determined from the formula for non-independent input data:

$$
u_{B}(d S)=\sqrt{\begin{array}{l}
u_{B}^{2}(S)+u_{B}^{2}(S)- \\
+2 u_{B}(S) \cdot u_{B}(S) \cdot r\left(S_{1+i-1}, S_{2+i}\right)
\end{array}}
$$

The uncertainty of the integer $\int \mathrm{pdS}$ (equation 2) can be evaluated as a geometric sum of the elementary trapezoids surface uncertainties:

$$
\mathrm{u}_{\mathrm{B}}(\mathrm{pdS})=\sqrt{\left(\mathrm{p}_{\mathrm{av}} \cdot \mathrm{u}_{\mathrm{B}}(\mathrm{d} S)\right)^{2}+\left(\mathrm{dS} \cdot \mathrm{u}_{\mathrm{B}}\left(\mathrm{p}_{\mathrm{av}}\right)\right)^{2}}
$$

and further:

$$
\mathrm{u}_{\mathrm{B}}(j \mathrm{pdS})=\sqrt{\sum_{1=1}^{\mathrm{i}=\mathrm{n}}\left(\mathrm{u}_{\mathrm{B}}\left(\mathrm{p}_{\mathrm{i}} \mathrm{d} \mathrm{S}_{\mathrm{i}}\right)\right)^{2}}
$$

Consequently the uncertainty of the indicated work:

$$
\mathrm{u}_{\mathrm{B}}\left(\mathrm{L}_{\mathrm{i}}\right)=\sqrt{\left(\mathrm{A} \cdot \mathrm{u}_{\mathrm{B}}(\mathrm{pdS})\right)^{2}+\left(\mathrm{pdS} \cdot \mathrm{u}_{\mathrm{B}}(\mathrm{A})\right)^{2}}
$$

where: $u_{B}\left(L_{i}\right)$ - indicated work standard uncertainty type $\mathrm{B}[\mathrm{J}]$.

The indicated power uncertainty of category I, based on the formula (1), can be determined as follows:

$$
\mathrm{u}_{\mathrm{BI}}\left(\mathrm{P}_{\mathrm{i}}\right)=\sqrt{\left(\frac{\partial \mathrm{P}_{\mathrm{i}}}{\partial \mathrm{L}_{\mathrm{i}}} \mathrm{u}_{\mathrm{B}}\left(\mathrm{L}_{\mathrm{i}}\right)\right)^{2}+\left(\frac{\partial \mathrm{P}_{\mathrm{i}}}{\partial \omega} \mathrm{u}_{\mathrm{c}}(\omega)\right)^{2}}
$$

where: $\mathrm{u}_{\mathrm{BI}}\left(\mathrm{P}_{\mathrm{i}}\right)$ - indicated power standard uncertainty type $\mathrm{B}$, category I [W].

For the purpose of category II indicated power uncertainty determination the indicated power is to be calculated for three cases. The first case is for the expected zero - value of $\varphi_{\mathrm{s}}$. The second and third cases are for its two boundary values, being in fact the phase shift angle uncertainties. For this purpose two additional courses of piston position should be found respectively for the lower and for the upper boundary value of $u_{B}\left(\varphi_{s}\right)$ :

$$
\begin{aligned}
\mathrm{S}(\mathrm{t}) & =\mathrm{r}\left(1-\cos \left(\omega \mathrm{t} \pm \mathrm{u}_{\mathrm{B}}\left(\varphi_{\mathrm{s}}\right)\right)\right)+ \\
& +1 \cdot\left(1-\sqrt{1-\left(\frac{\mathrm{r}}{1}\right)^{2} \sin ^{2}\left(\omega \mathrm{t} \pm \mathrm{u}_{\mathrm{B}}\left(\varphi_{\mathrm{s}}\right)\right)}\right)
\end{aligned}
$$

Two additional indicated powers can be defined as: $\mathrm{P}_{\mathrm{i} @-\mathrm{u}_{\mathrm{B}}\left(\varphi_{\mathrm{s}}\right)}$ - indicated power for the lower phase shift angle uncertainty boundary,

$\mathrm{P}_{\mathrm{i} @+\mathrm{u}_{\mathrm{B}}\left(\varphi_{\mathrm{s}}\right)}$ - indicated power for the upper phase shift angle uncertainty boundary.

\section{Wyznaczanie całkowitej niepewności mocy indykowanej}

Obliczenia przeprowadzono na przykładzie dwóch silników okrętowych różnej konstrukcji:

- bezwodzikowego silnika Hyundai Himsen H25/33,

- wodzikowego silnika MAN K90 MC-C.

Przeanalizowano dane z pomiaru mocy indykowanej pojedynczego cylindra za pomocą typowego przemysłowego indykatora cyfrowego. Całkowita niepewność mocy indykowanej typu B była rozpatrywana jako złożenie niepewności dwóch rodzajów. Pierwszą jest złożona niepewność ze względu na niepewność poszczególnych wielkości występujących w równaniach (1), (2) i (12). Ta część niepewności mocy indykowanej została określona niepewnością rodzaju I. Drugą z nich jest niepewność wynikająca bezpośrednio $\mathrm{z}$ istnienia niezerowej wartości niepewności kąta przesunięcia fazowego uB(js). Ta część niepewności mocy indykowanej została określona niepewnością rodzaju II.

Do wyznaczenia niepewności rodzaju I obliczono niepewność wyznaczenia położenia tłoka $\mathrm{u}_{\mathrm{B}}(\mathrm{S})$-równanie (15), gdzie: $u_{B}(S)$ - niepewność standardowa typu B wyznaczenia położenia tłoka [m], S(t) - przemieszczenie tłoka w funkcji czasu $[\mathrm{m}]$,

Wartość niepewności $u_{\mathrm{B}}(\mathrm{S})$ jest niezależna od chwilowego położenia tłoka przy założeniu, że prędkość kątowa wału korbowego jest stała, dlatego można przyjąć upraszczające założenie, że niepewności kolejnych obliczonych położeń tłoka $\mathrm{S}_{\mathrm{i}}$ wynikających z cyfrowego charakteru pomiaru są sobie równe (16).

Wartość elementarnego przesunięcia tłoka dS ${ }_{\mathrm{i}}$ pomiędzy jego kolejnymi obliczonymi położeniami wyznaczana jest $\mathrm{z}$ różnicy (17).

Ponieważ zbiory kolejnych położeń tłoka są silnie skorelowane ze współczynnikiem korelacji $\mathrm{r}\left(\mathrm{S}_{1+\mathrm{i}-1}, \mathrm{~S}_{2+\mathrm{i}}\right)$ bliskim jedności, niepewność elementarnego przesunięcia tłoka $\mathrm{u}_{\mathrm{B}}(\mathrm{dS})$ może być wyznaczona za pomocą równania dla skorelowanych wielkości wejściowych (18).

Niepewność całki jpdS (równanie (2)) można wyznaczyć jako geometryczną sumę niepewności powierzchni elementarnych trapezów (19) i (20).

Konsekwentnie niepewność pracy indykowanej wyznaczana jest $\mathrm{z}$ zależności $(21)$, gdzie: $\mathrm{u}_{\mathrm{B}}\left(\mathrm{L}_{\mathrm{i}}\right)$ - niepewność standardowa typu B pracy indykowanej $[\mathrm{J}]$.

Niepewność mocy indykowanej rodzaju I, opierając się na równaniu (1), można ostatecznie wyznaczyć $\mathrm{z}$ równania (22), gdzie: $u_{\mathrm{BI}}\left(\mathrm{P}_{\mathrm{i}}\right)$ - niepewność standardowa mocy indykowanej typu B, I rodzaju [W].

Aby możliwe było określenie wartości niepewności mocy indykowanej rodzaju II, należy wyznaczyć moc indykowaną dla trzech przypadków. W pierwszym obliczenia prowadzi się dla oczekiwanej wartości kąta przesunięcia fazowego $\varphi_{\mathrm{s}}$ wynoszącej zero. $\mathrm{W}$ dwóch kolejnych przypadkach do obliczeń przyjmuje się wartości graniczne tego kąta, będące W rzeczywistości wartościami jego niepewności $\mathrm{u}_{\mathrm{B}}\left(\varphi_{\mathrm{s}}\right)$. $\mathrm{W}$ tym celu konieczne jest wyznaczenie przebiegu przemieszczenia tłoka odpowiednio dla dolnej i górnej wartości niepewności $\mathrm{u}_{\mathrm{B}}\left(\varphi_{\mathrm{S}}\right)$ - równanie (23). 
Table 2. The results of calculated partial uncertainties and the final uncertainty of the measured indicated power

Tabela 2. Wyniki obliczonych niepewności cząstkowych oraz końcowe niepewności mocy indykowanej

\begin{tabular}{|c|c|c|}
\hline \multirow[t]{2}{*}{ Step of calculations/etap obliczeń } & \multicolumn{2}{|c|}{ Result/wyniki } \\
\hline & H25/33 engine/silnik & K90 MC-C engine/silnik \\
\hline Relative load/względne obciążenie & $59 \% \mathrm{MCR}$ & $80 \% \mathrm{MCR}$ \\
\hline$\frac{\partial \mathrm{S}}{\partial \mathrm{t}} \mathrm{u}_{\mathrm{B}}(\mathrm{t})$ & $10.2 \mu \mathrm{m}$ & $8.40 \mu \mathrm{m}$ \\
\hline$\frac{\partial \mathrm{S}}{\partial \omega} \mathrm{u}_{\mathrm{c}}(\omega)$ & $1.00 \mu \mathrm{m}$ & $5.20 \mu \mathrm{m}$ \\
\hline$\frac{\partial \mathrm{S}}{\partial \varphi_{\mathrm{s}}} \mathbf{u}_{\mathrm{B}}\left(\varphi_{\mathrm{s}}\right)$ & $39.4 \mu \mathrm{m}$ & $274 \mu \mathrm{m}$ \\
\hline$\frac{\partial \mathrm{S}}{\partial \mathrm{r}} \mathrm{u}_{\mathrm{B}}(\mathrm{r})$ & $<1.00 \mu \mathrm{m}$ & $<1.00 \mu \mathrm{m}$ \\
\hline$\frac{\partial \mathrm{S}}{\partial \mathrm{l}} \mathrm{u}_{\mathrm{B}}(\mathrm{l})$ & $<1.00 \mu \mathrm{m}$ & $<1.00 \mu \mathrm{m}$ \\
\hline $\mathrm{u}_{\mathrm{B}}(\mathrm{S})$ & $40.7 \mu \mathrm{m}$ & $274 \mu \mathrm{m}$ \\
\hline $\mathrm{u}_{\mathrm{B}}(\mathrm{dS})$ & $1.00 \mu \mathrm{m}$ & $4.80 \mu \mathrm{m}$ \\
\hline $\mathrm{L}_{\mathrm{i}}$ & $23.9 \mathrm{~kJ}$ & $2360 \mathrm{~kJ}$ \\
\hline $\mathrm{u}_{\mathrm{B}}\left(\mathrm{L}_{\mathrm{i}}\right)$ & $\pm 1.00 \mathrm{~kJ}( \pm 2.40 \%)$ & $\pm 53.3 \mathrm{~kJ}( \pm 2.3 \%)$ \\
\hline $\mathrm{P}_{\mathrm{i}}$ & $182 \mathrm{~kW}$ & $3850 \mathrm{~kW}$ \\
\hline $\mathrm{u}_{\mathrm{BI}}\left(\mathrm{P}_{\mathrm{i}}\right)$ & $\pm 8.9 \mathrm{~kW}( \pm 4.9 \%)$ & $\pm 95 \mathrm{~kW}( \pm 2.5 \%)$ \\
\hline $\mathrm{u}_{\mathrm{BII}}\left(\mathrm{P}_{\mathrm{i}}\right)$ & $\pm 8.6 \mathrm{~kW}( \pm 4.7 \%)$ & $\pm 160 \mathrm{~kW}( \pm 4.1 \%)$ \\
\hline $\mathrm{u}_{\mathrm{C}}\left(\mathrm{P}_{\mathrm{i}}\right)$ & $\pm 12 \mathrm{~kW}( \pm 6.8 \%)$ & $\pm 180 \mathrm{~kW}( \pm 4.8 \%)$ \\
\hline
\end{tabular}

The difference between indicated power calculated for $\varphi_{\mathrm{s}}=0$, and indicated power calculated for $\varphi_{\mathrm{s}}= \pm \mathrm{u}_{\mathrm{B}}\left(\varphi_{\mathrm{s}}\right)$ respectively can be defined as the indicated power uncertainty due to phase shift angle $\varphi_{\text {s }}$. Both values may differ due to asymmetric pressure flow in relation to TDC. Simplification of the calculations seems to be a good reason to determine category II indicated power uncertainty as an average:

$$
u_{\mathrm{BII}}\left(\mathrm{P}_{\mathrm{i}}\right)=\frac{\left|\mathrm{P}_{\mathrm{i}}-\mathrm{P}_{\mathrm{i} @-\mathrm{u}_{\mathrm{B}}\left(\varphi_{\mathrm{s}}\right)}\right|+\left|\mathrm{P}_{\mathrm{i}}-\mathrm{P}_{\mathrm{i} @+\mathrm{u}_{\mathrm{B}}\left(\varphi_{\mathrm{s}}\right)}\right|}{2}
$$

where: $\mathrm{u}_{\mathrm{BII}}\left(\mathrm{P}_{\mathrm{i}}\right)$ - indicated power standard uncertainty type $\mathrm{B}$, category II [W], $\mathrm{P}_{\mathrm{i}}$ - indicated power for expected value of the phase shift angle $\varphi_{\mathrm{s}}=0, \mathrm{P}_{\mathrm{i} @-\mathrm{u}_{\mathrm{B}}\left(\varphi_{\mathrm{s}}\right)}$ - indicated power for the lower phase shift angle uncertainty boundary, $\mathrm{P}_{\mathrm{i} @+\mathrm{u}_{\mathrm{B}}\left(\varphi_{\mathrm{s}}\right)}$ - indicated power for the upper phase shift angle uncertainty boundary.

The total combined indicated power standard uncertainty comes from the law of propagation of uncertainty:

$$
\mathrm{u}_{\mathrm{cB}}\left(\mathrm{P}_{\mathrm{i}}\right)=\sqrt{\mathrm{u}_{\mathrm{BI}}\left(\mathrm{P}_{\mathrm{i}}\right)^{2}+\mathrm{u}_{\mathrm{BI}}\left(\mathrm{P}_{\mathrm{i}}\right)^{2}}
$$

where: $\mathrm{u}_{\mathrm{cB}}\left(\mathrm{P}_{\mathrm{i}}\right)$ - overall indicated power standard uncertainty type $\mathrm{B}[\mathrm{W}]$.

In the case where the indicator is capable of determining the indicated power for every singular engine cycle of the measured series, the uncertainty of type A may be taken into account:
Dwie dodatkowo obliczone wartości mocy indykowanej można opisać w następujący sposób:

$\mathrm{P}_{\mathrm{i} @-\mathrm{u}_{\mathrm{B}}\left(\varphi_{\mathrm{s}}\right)}-\mathrm{moc}$ indykowana dla dolnej granicy niepewności kąta przesunięcia fazowego,

$\mathrm{P}_{\mathrm{i} @+\mathrm{u}_{\mathrm{B}}\left(\varphi_{\mathrm{s}}\right)}-\mathrm{moc}$ indykowana dla górnej granicy niepewności kąta przesunięcia fazowego.

Różnica pomiędzy wartością mocy indykowanej obliczonej dla $\varphi_{\mathrm{s}}=0$ a mocą indykowaną wyznaczoną odpowiednio dla $\varphi_{\mathrm{s}}= \pm \mathrm{u}_{\mathrm{B}}\left(\varphi_{\mathrm{s}}\right)$ może być rozumiana jako niepewność mocy indykowanej ze względu na kąt przesunięcia fazowego $\varphi_{\mathrm{s}}$. Wartości obu różnic mogę się różnić ze względu na niesymetryczność przebiegu ciśnienia względem GMP. Uproszczenie obliczeń wydaje się jednak wystarczającym argumentem, aby wartość niepewności mocy indykowanej rodzaju II wyznaczać jako średnią arytmetyczną tych wartości (24), gdzie: $\mathrm{u}_{\mathrm{BII}}\left(\mathrm{P}_{\mathrm{i}}\right)$ - niepewność standardowa mocy indykowanej typu B, II rodzaju [W], $\mathrm{P}_{\mathrm{i}}$ - moc indykowana dla oczekiwanej wartości kąta przesunięcia fazowego $\varphi_{\mathrm{s}}=0, \mathrm{P}_{\mathrm{i} @-\mathrm{u}_{\mathrm{B}}\left(\varphi_{\mathrm{s}}\right)}-$ moc indykowana dla dolnej granicy niepewności kąta przesunięcia fazowego, $\mathrm{P}_{\mathrm{i} @+\mathrm{u}_{\mathrm{B}}\left(\varphi_{\mathrm{s}}\right)}-$ moc indykowana dla górnej granicy niepewności kąta przesunięcia fazowego.

Całkowita, złożona niepewność standardowa mocy indykowanej wyznaczana jest za pomocą prawa propagacji niepewności (25), gdzie: $\mathrm{u}_{\mathrm{cB}}\left(\mathrm{P}_{\mathrm{i}}\right)$ - całkowita niepewność standardowa mocy indykowanej typu B [W].

Gdy indykator umożliwia określenie mocy indykowanej każdego z serii zmierzonych cykli pracy, możliwe jest również uwzględnienie niepewności typu A - równanie (26), 

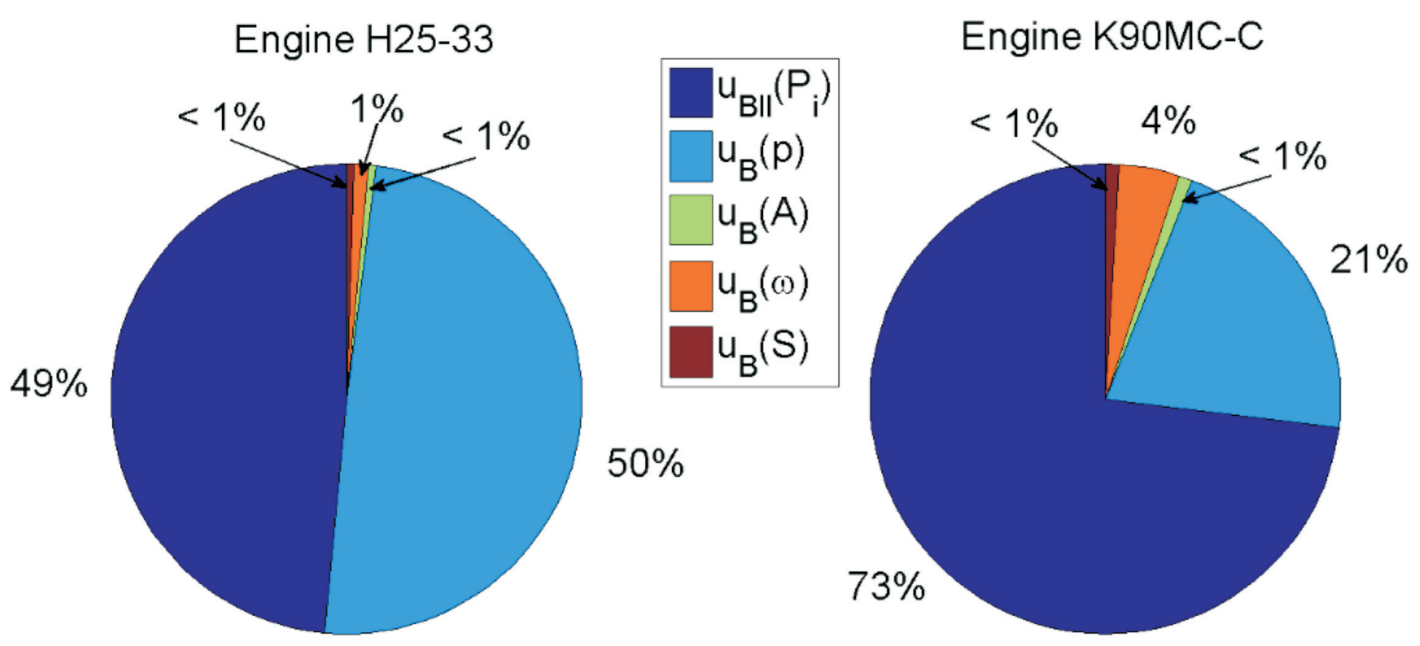

Fig. 2. Indicated power uncertainy structure for trunk piston engine type H25-33 and for crosshead engine type K90MC-C; uBII(Pi) - indicated power uncertainty type $B$ category II, $u_{B}(p)$ - in-cylinder pressure uncertainty, $u_{B}(A)$ - piston surface uncertainty, $u_{B}(\omega)-$ crankshaft angular speed uncertainty; $\mathrm{u}_{\mathrm{B}}(\mathrm{S})$ - piston position uncertainty

Rys. 2. Struktura niepewności mocy indykowanej silnika bezwodzikowego H25-33 i silnika wodzikowego K90MC-C; uBII(Pi) - niepewność mocy indykowanej typu B rodzaju II, $u_{B}(p)$ - niepewność pomiaru ciśnienia wewnatrzcylindrowego, $u_{B}(A)$ - niepewność wyznaczenia powierzchni denka tłoka, $u_{B}(\omega)$ - niepewność pomiaru prędkości kątowej watu korbowego; $u_{B}(S)$ - niepewność wyznaczenia położenia tłoka

$$
u_{c}\left(P_{i}\right)=\sqrt{u_{B I}\left(P_{i}\right)^{2}+u_{B I I}\left(P_{i}\right)^{2}+u_{A}\left(P_{i}\right)^{2}}
$$

where: $u_{c}\left(P_{i}\right)$ - overall complex indicated power standard uncertainty $[\mathrm{W}], \mathrm{u}_{\mathrm{A}}\left(\mathrm{P}_{\mathrm{i}}\right)$ - indicated power standard uncertainty type $\mathrm{A}[\mathrm{W}]$.

The results of a calculation for real engines and real data from a commercial indicator are presented in Table 2. The standard uncertainties are calculated for the estimated confidence level of $68 \%$.

Additionally the structure of the uncertainties for both engines is shown on Figure 2. In order to facilitate the evaluation of the contribution of certain basic components in the overall indicated power uncertainty, the uncertainty $\mathrm{u}_{\mathrm{BI}}\left(\mathrm{P}_{\mathrm{i}}\right)$ of the category I was split into: $u_{B}(p), u_{B}(A), u_{B}(\omega), u_{B}(S)$. The domination of two sources of uncertainty: uncertainty type $\mathrm{B}$ category $\mathrm{II}-\mathrm{u}_{\mathrm{BII}}\left(\mathrm{P}_{\mathrm{i}}\right)$ and the in-cylinder pressure measurement uncertainty $u_{B}(p)$ is noticeable.

\section{Summary}

There is no standardized method of the indicated power uncertainty determination available. A fast development of the measurement methods as well as the marine engines control and automation systems seem to be a good reason for the systematization of uncertainty determination. In order to develop an algorithm suitable for application in industrial conditions it was necessary to introduce the division of the indicated power uncertainty type B into category I and II. Some parameters (Table 1) which are usually difficult to measure can be assumed based on the personnel experience or knowledge of the specific engine construction and load. It is noticeable that the piston position uncertainty $u_{B}(S)$ is influenced mainly by the phase shift angle uncertainty $u_{B}\left(\varphi_{s}\right)$. Therefore the value of $u_{B}\left(\varphi_{s}\right)$ becomes the main determinant gdzie: $\mathrm{u}_{\mathrm{c}}\left(\mathrm{P}_{\mathrm{i}}\right)$ - całkowita, złożona niepewność standardowa mocy indykowanej $[\mathrm{W}], \mathrm{u}_{\mathrm{A}}\left(\mathrm{P}_{\mathrm{i}}\right)$ - niepewność standardowa typu A pomiaru mocy indykowanej [W].

Wyniki obliczeń przeprowadzonych na podstawie rzeczywistych danych silników uzyskane za pomocą przemysłowego indykatora zebrano w tabeli 2 . Niepewności standardowe wyznaczono dla szacunkowej wartości poziomu ufności wynoszącego 68\%. Ponadto na rysunku 2 przedstawiono strukturę całkowitej, złożonej niepewności standardowej dla obydwu silników. Aby ułatwić ocenę udziału składników w ogólnej wartości niepewności mocy indykowanej, wartość niepewności $\mathrm{u}_{\mathrm{BI}}\left(\mathrm{P}_{\mathrm{i}}\right)$ rodzaju I celowo została rozbita na poszczególne niepewności jej podstawowych składników, zgodnie $z$ równaniami (21) i (22): $u_{B}(p), u_{B}(A), u_{B}(\omega), u_{B}(S)$. Wyraźnie zauważalna jest dominacja dwóch źródeł niepewności: typu $\mathrm{B}$ rodzaju II $-\mathrm{u}_{\mathrm{BII}}\left(\mathrm{P}_{\mathrm{i}}\right)$ oraz niepewność pomiaru ciśnienia wewnątrz cylindrowego $\mathrm{u}_{\mathrm{B}}(\mathrm{p})$.

\section{Podsumowanie}

Nie istnieje standardowa metoda wyznaczania niepewności mocy indykowanej. Usystematyzowanie metody jej wyznaczania uzasadnia szybki rozwój metod pomiarowych, a zwłaszcza rozwój metod kontroli i sterowania pracą silników okrętowych. Opracowanie algorytmu obliczeniowego nadającego się do zastosowania w warunkach przemysłowych wymusiło konieczność wprowadzenia podziału niepewności mocy indykowanej typu B na niepewność rodzaju I oraz niepewność rodzaju II. Niektóre wielkości (tab. 1), zwykle trudne do zmierzenia, mogą być oszacowane na podstawie doświadczenia i wiedzy osób wykonujących pomiar na temat szczególnych uwarunkowań konstrukcji i obciążenia silnika. Warto podkreślić, że na niepewność położenia tłoka $u_{\mathrm{B}}(\mathrm{S})$ ma wpływ głównie niepewność kąta 
of the value of both categories I and II of indicated power uncertainties. The second biggest source of indicated power uncertainty is the uncertainty of the in-cylinder pressure measurement. Especially in case where the measurement is carried out in unfavorable conditions, like pressure resonance in a long indicating channel or when the measuring range of the pressure sensor is much greater than the measured values, the influence of this uncertainty may be comparable with $\mathrm{u}_{\mathrm{BII}}\left(\mathrm{P}_{\mathrm{i}}\right)$. In order to reduce the overall uncertainty of the determined indicated power mainly the uncertainty of the measured pressure and uncertainty of the phase shift angle should be reduced.

The practical advantage of the presented method of uncertainty evaluation is that it can be easily applied in the algorithms of typical digital indicators. It would be sufficient to allow personnel to input a few additional data characterizing the engine and the measuring equipment as well as estimated parameters such as TDC pick-up installation accuracy which can be subjectively evaluated by the measurer. przesunięcia fazowego $u_{B}\left(\varphi_{s}\right)$, dlatego wartość $u_{B}\left(\varphi_{s}\right)$ jest dominującym składnikiem obydwu niepewności mocy indykowanej: rodzaju I oraz rodzaju II. Drugim co do wielkości źródłem niepewności mocy indykowanej jest niepewność pomiaru ciśnienia wewnątrz cylindrowego. Przybiera ona na znaczeniu w szczególności wtedy, gdy pomiar dokonywany jest w niekorzystnych warunkach, jak pojawianie się rezonansu gazu w długim kanale indykatorowym, lub gdy zakres pomiarowy czujnika ciśnienia jest znacznie większy niż wartość mierzonych ciśnień. Wówczas niepewność wynikająca z pomiaru ciśnienia może być porównywalna do niepewności $\mathrm{u}_{\mathrm{BII}}\left(\mathrm{P}_{\mathrm{i}}\right)$. W celu zminimalizowania całkowitej niepewności wyznaczonej mocy indykowanej należy skupić się głównie na redukcji niepewności tych dwóch składników: niepewności kąta przesunięcia fazowego oraz niepewności ciśnienia cylindrowego.

Prezentowana metoda wyznaczania niepewności mocy indykowanej może być łatwo zaimplementowana w oprogramowaniu typowych indykatorów przemysłowych, co stanowi jej dużą zaletę. W oprogramowaniu indykatora wystarczające byłoby umożliwienie wprowadzenia dodatkowych danych charakteryzujących przyrządy pomiarowe, silnik oraz dane szacunkowe, jak np. dokładność mocowania czujnika GMP oceniona subiektywnie przez dokonującego pomiaru.

\section{Bibliography/Literatura}

[1] Brown W.L. Methods for evaluating requirements and errors in cylinder pressure measurement. SAE Technical Paper, nr 670008. 1967.

[2] International Organization for Standardisation, Guide to the expression of uncertainty in measurement, 1995, ISBN 92-6710188-9.

[3] Eutowicz M., Cuper D. Influence of indicator valve channel untightens and loss of patency on the parameters values image obtained from indicator diagram, Journal of KONES Powertrain and Transport, Vol.18, No 3, s. 61-66, Warszawa 2011.

[4] Kowalak P. Experimental determination of low speed diesel engine crankshaft twisting. Journal of Polish CIMAC, Vol.3, No.2. s. 9-13. Warsaw. 2008. ISSN 1231-3998.

[5] Kowalak P. Speed irregularity characteristic of low speed, two-stroke marine diesel engine applied as vessel's main propulsion. Journal of KONES Powertrain and Transport, Vol.15, No.4. s. 263-268. Warsaw. 2008. ISSN 1231-4005.

[6] Staś M.J. An universally applicable thermodynamic method for TDC determination. SAE Technical Papers, nr 2000-01-0561. 2000.

[7] Tazerout M., Le Corre O., Rousseau S. TDC determination in IC engines based on the thermodynamic analysis of the temperature-entropy diagram. SAE Technical Paper, nr 199901-1489. 1999.
[8] Wajand J. Pomiary szybkozmiennych ciśnień w maszynach tłokowych. Wydawnictwa Naukowo-Techniczne. Warszawa 1974.

[9] Walter T., Gossweiler C., Willson B. Application of an improved model for the determination of acoustic resonances in indicator passages for combustion pressure measurements. ASME 2006 Internal Combustion Engine Division Spring Technical Conference, Paper No. ICES2006-1373, s. 769-779. Aachen 2006. ISBN: 0-7918-4206-1.

[10] Wimmer A., Glaser J. Indykowanie silnika. Instytut Zastosowań Techniki Sp. z o.o. Warszawa 2004. ISBN 83-88691$20-1$.

Przemysław Kowalak, DEng., Marine Chief Engineer - doctor in the Chair of Marine Engines, Faculty of Marine Engineering at Maritime University of Szczecin.

Dr inż. Przemystaw Kowalak, starszy mechanik okrętowy - adiunkt w Zakladzie Silników Okrętowych, Wydziału Mechanicznego Akademii Morskiej w Szczecinie.

e-mail:p.kowalak@am.szczecin.pl

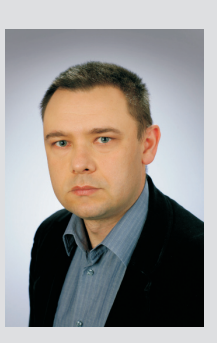

